\title{
AGRARIAN-ECONOMIC STRUCTURE OF AGRICULTURAL HOLDINGS IN POLAND AND EAST GERMANY: SELECTED ELEMENTS OF COMPARATIVE ANALYSIS
}

\author{
ALEKSANDRA JEZIERSKA-ThÖLE ${ }^{1}$, JÖRG JANZEN² ${ }^{2}$, ROMAN RUdNICKI ${ }^{1}$ \\ ${ }^{1}$ Department of Spatial Management and Tourism, Faculty of Earth Sciences, Nicolaus Copernicus University, \\ Toruń, Poland \\ ${ }^{2}$ Institute of Geographical Sciences, Free University of Berlin, Berlin, Germany
}

Manuscript received: July 31, 2013

Revised version: March 6, 2014

JeZIerSKa-ThöLe A., JANZen J., Rudnicki R., 2014. Agrarian-economic structure of agricultural holdings in Poland and East Germany: Selected elements of comparative analysis. Quaestiones Geographicae 33(2), Bogucki Wydawnictwo Naukowe, Poznań, pp. 87-101, 4 tables, 8 figs. DOI 10.2478/quageo-2014-0018, ISSN 0137-477X.

\begin{abstract}
Aвstract: The aim of this study was to determine differences in the development of farms in Poland against the agriculture of East Germany, and to show areas with similar conditions for development. The time range of the research covered the years 2002-2010, i.e. the stage of preparation of Polish agriculture for accession to the European Union, the implementation of pre-accession aid programmes, and the establishment and implementation of the tools of the Common Agricultural Policy. To assess the level of agricultural development, natural, productive and social characteristics were adopted. Spatial variations in the analysed features were based on the variation coefficient $\left(\mathrm{V}_{\mathrm{z}}\right)$, and the level of agricultural development, on Perkal's index $\left(\mathrm{W}_{\mathrm{i}}\right)$. In the analysed period the range of variation and the degree of the spatial dispersion of sub-indices changed, indicating a deepening of the polarisation processes in agriculture. The implementation of CAP intensified the process of specialisation and modernisation in agriculture, an example of which is the increase in the average farm size and in agricultural productivity. On the other hand, agricultural production intensified, as exemplified by a decrease in the minimum value in six of the analysed characteristics, which indicates growing disparities.
\end{abstract}

KEY WORDS: agriculture, agrarian structure, crop and animal production, Poland, Germany

Aleksandra Jezierska-Thöle, Roman Rudnicki, Department of Spatial Management and Tourism, Faculty of Earth Sciences, Nicolaus Copernicus University, Lwowska 1,87-100 Toruń, Poland; e-mail:alekjez@umk.pl, rudnickir@umk.pl Jörg Janzen, Institut für Geographische Wissenschaften, Fachrichtung Anthropogeographie, Malteserstr. 74-100, 12249 Berlin, Germany; e-mail: janzen@geog.fu-berlin.de

\section{Introduction}

The integration of Poland with the European Union has created new conditions for the development of its rural areas and agriculture. By becoming a full member of the EU Poland was obliged to implement the Common Agricultural Policy (CAP), which aims to increase agricultural productivity and stabilise agricultural markets by subsidising agricultural production and introducing the principles of environmental protection into farming. The Polish agricultural economy had to face new challenges of the free agricultural market, which undoubtedly contributed to structural changes in agriculture. The adoption of the European model of supporting agriculture resulted in the implementation of direct subsidies with accompanying measures as well as other CAP instruments financed by the Guarantee Section of the European Agricultur- 
al Guidance and Guarantee Fund (EAGGF). As a member of the EU, Polish agriculture has implemented a number of programmes aimed at improving the economy of farms and increasing their competitiveness on the common European food market.

In the years 2004-2006, the support for Polish agriculture was granted under the direct subsidies scheme (the single area payment scheme - SAPS - and complementary national area payments) as well as two programmes: the Sectoral Operational Programme "Restructuring and modernisation of the food sector and rural development" and the Rural Development Plan. In the years 2007-2013 the funding for agricultural development was obtained under the system of direct payments and the Rural Development Programme (RDP), which consists of a series of measures, partly continued from the previous programming period (Rudnicki 2010). Those measures were included in four priorities: Improvement of the competitiveness of agriculture and forestry, Improvement of the environment and rural areas, Improvement of the quality of life in rural areas, and Diversification of the rural economy (Obszary ... 2009).

Following the direction of the CAP reform, the Polish Ministry of Agriculture and Rural Development developed the Strategy for Agricultural Development (SAD) for the period of 2007-2013. It defined the main problems and opportunities for the development of Polish agriculture. The prioritised measure was "to improve the efficiency and profitability of farms by their modernising and changing agricultural structures" (Strategia ... 2005: 3). According to the strategy, farmers' participation in the market of agricultural products should also be strengthened.

Given the above strategic goals and objectives of the structural changes in Polish agriculture resulting from both the CAP and SAD, the research was conducted on the processes occurring in agricultural holdings: their agrarian, social, economic and production structure. The main aim of the study was to determine the quantitative, qualitative and spatial nature as well as the direction of change. This article also covers the results of field studies carried out in rural areas of East Germany by students and researchers of the Free University in Berlin and Nicolaus Copernicus
University in Torun, funded by the DAAD and KAAD.

\section{Study area, purpose and objectives of the research}

In order to capture structural changes in Polish agriculture and determine the nature and pace of the development of agriculture, a comparison was made with a neighbouring country, viz. Germany, which has a high share in the EU agricultural production (13.1\%). The selection of East Germany for the comparative analysis was associated with the fact that it has similar natural, political and historic conditions. Arable land in both Poland and Germany accounts for more than half of the country's surface area (Poland 59.7\%, Germany 52\%). Poland and the eastern Länder of Germany belonged to the 'eastern bloc' states, in different ways implementing the socialist model of agriculture which aimed to enlarge the area of 'socialised' farms as cooperatives and state farms. In the former German Democratic Republic (GDR) this objective was achieved, as $94.5 \%$ of agricultural land was in the socialised sector. The private sector accounted for a mere $5.5 \%$. Poland was the only country among the eastern bloc states (besides the former Yugoslavia) in which $78 \%$ of land was kept in private ownership. After 1989, both Poland and the former GDR went through a political transformation which evoked profound changes in the structure of agriculture. There appeared new processes of privatisation of state and cooperative farms, so far unheard of in the economic history of Europe (Hoffman 1993). The unification of Germany into a single state, part of the Socio-Economic and Monetary Union, which took place in July 1990, launched a series of measures to improve the economy of the agricultural sector, including the adoption of a new privatisation law and the introduction of the financing system under the EU's agricultural policy (Brem 2001). In Poland, the implementation of the Common Agricultural Policy only began with the country's accession to the EU in 2004. The core of the research problem is, therefore, a complete and accurate study of differences in the spatial structure of farms. 
Table 1. Characteristics adopted for the analysis of spatial differences in agricultural development in 2002-2010

\begin{tabular}{|c|c|}
\hline $\begin{array}{c}\text { Sym- } \\
\text { bol }\end{array}$ & Characteristic \\
\hline$X_{1}$ & Share of agricultural land in total area (\%) \\
\hline$X_{2}$ & $\begin{array}{c}\text { Share of arable land in total agricultural land } \\
(\%)\end{array}$ \\
\hline$X_{3}$ & Cereal yields in dt/ha \\
\hline$X_{4}$ & Potato yields in dt/ha \\
\hline$X_{5}$ & Oilseed yields in dt ha \\
\hline$X_{6}$ & Sugar beet yields in dt/ha \\
\hline$X_{7}$ & Cattle - livestock units per 100 ha of agricultur- \\
\hline$X_{8}$ & Pigs per 100 ha of agricultural land \\
\hline$X_{9}$ & Sheep per 100 ha of agricultural land \\
\hline$X_{10}$ & Average size of farms in ha \\
\hline$X_{11}$ & Number of workers on farms of 100 ha of \\
\end{tabular}

Source: own calculations based on Jasiulewicz (1998) and Rudnicki (2010)

The time horizon of the study includes the years 2002 to 2010 . This is a period between two censuses in agriculture. It includes the preparatory stage of Polish agriculture before accession to the European Union, i.e. the adaptation of national agricultural policy to the EU standards and requirements (acquis communautaire) and the implementation of pre-accession aid programmes (2002-2004). Since 2004, this was the period of start-up and implementation of the tools of the Common Agricultural Policy.

This paper includes the following phases of research:

1. Spatial analysis of changes in selected sub-indices $\left(X_{1} \ldots X_{11}\right)$,

2. Determination of spatial differences in the sub-indices based on the coefficient of variation (the ratio of the standard deviation of a given feature to the arithmetic mean, expressed as a percentage) $\left(\mathrm{V}_{\mathrm{z}}\right)$, and

3. Identification of changes in the spatial distribution rate of Perkal's index and determination of the nature and pace of development $\left(\mathrm{W}_{\mathrm{i}}\right)$.

To assess the level of agricultural development, the following groups of characteristics were adopted:

1. A group of natural features - expressing potential soil quality and the potential of the land for crop production,
2. A group of production features - expressing potential crop and livestock production as well as the organisational and production capacity, and

3. A group of social characteristics - expressing the labour force potential in agriculture.

The choice of the indicators and research area led to the delimitation of common processes in agriculture and to identification of new measures designed to compensate for differences in development (Table 1).

The above features are stimulants. Then, using Perkal's method, a synthetic indicator of the level of agricultural development was calculated. The use of Perkal's synthetic measure allowed arranging regions by a synthetic indicator, which is a function of many variables. This method consisted of two phases: normalisation of individual measurements taken for testing and the calculation of the synthetic indicator of the level of regional development using a suitable formula (Szymla 2000, Namyślak 2007). This method allowed presenting the dynamics of change and determining development trends of the studied areas in subsequent periods, i.e. in 2002 and 2010.

\section{Recent trends in the structure of farmland use}

The delimitation of recent developmental trends in the farmland structure in Poland was based on the time range 2004-2010. This approach resulted from a change in the definition of utilised agricultural land and total agricultural land used by the Central Statistical Office in accordance with the Eurostat methodology (Official Gazette No. 46, item 306).

The share of agricultural land in the total area of the country is one of the most important indicators of the extent of farming. In 2010, Agricultural Census results showed that agricultural land used for farming was 15.5 million ha, or $49.6 \%$ of Poland's area (Uizytkowanie ... 2011). The voivodeships with the largest share of agricultural land included Wielkopolska and $\mathrm{Ku}-$ javia-Pomerania (60\%), followed by Mazovia $(56.7 \%)$ and Lublin $(56.4 \%)$. In 2002, the share of agricultural land in the total area was $58.8 \%$. The decrease in agricultural land is due, among 

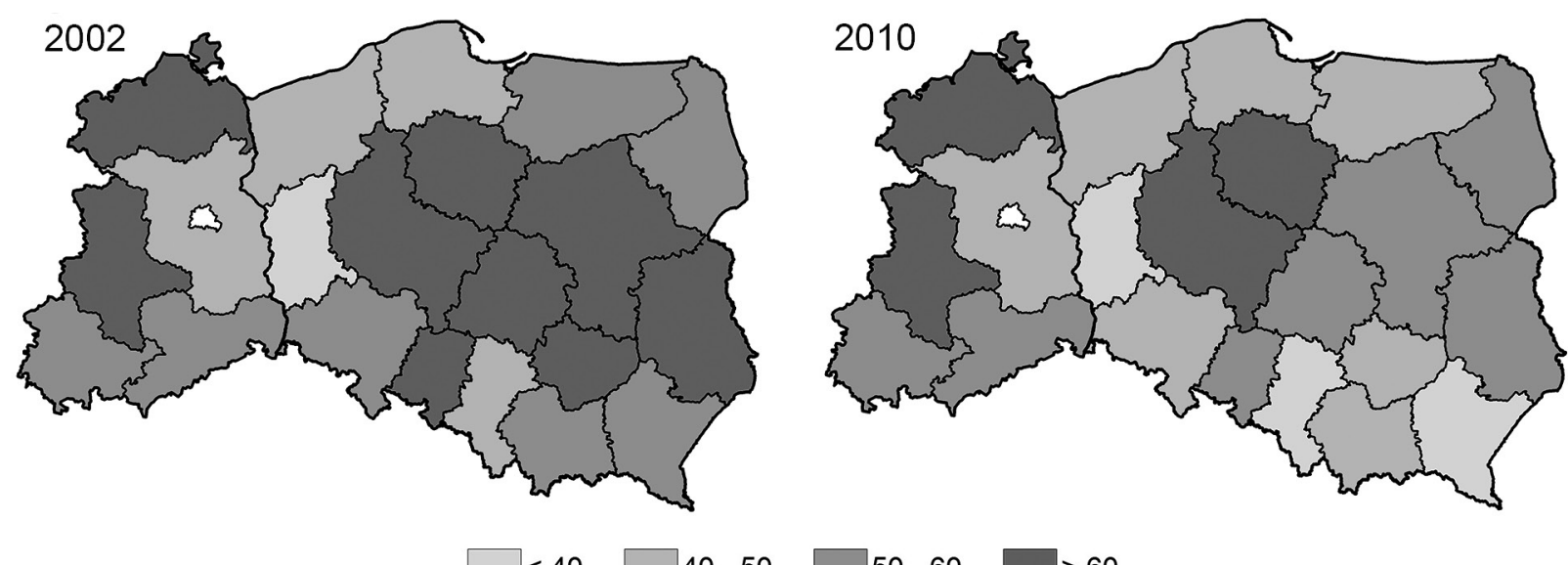

$<40 \square 40-50$

$50-60$

$>60$

Fig. 1. Share of farmland in voivodeships in Poland and Länder in East Germany in 2002 and 2010 (\%) Source: authors' own calculation based on German 2011 data and Polish 2002 and 2010 Agricultural Censuses

other things, to the exclusion of about 3,000 ha per year for non-agricultural and non-forest purposes according to the existing regulations on the protection of agricultural and forest land (Official Gazette, 1995). The exemption of agricultural land is a permanent phenomenon related to urban sprawl and housing, the development of associated infrastructure, and the construction of roads and highways. After 2006 it was noted that the area of farmland increased slightly due to the introduction of direct payments for agricultural land (Fig. 1).

In 2010, the proportion of arable land varied spatially, from over $80 \%$ in Opole $(89 \%), \mathrm{Ku}-$ javia-Pomerania (84\%) and Wielkopolska (83\%) voivodeships to less than $60 \%$ in Małopolska $(50 \%)$ and Subcarpathia (52\%). Changes in arable land show increased intensification of crop production. The increase in the share of arable land comes at the cost of reducing the area taken up by orchards and meadows. Changes in agricultural land use resulted primarily from a change in the approach to its management. Two trends can be noted in the way agricultural land is used. On the one hand, there was an increase in production in areas with high-quality agricultural production space, resulting in a significant increase in yields. On the other hand, extensification of production was recorded in areas with a low value of the quality indicator. This is in line with the change in the approach to agriculture, which is to keep the land in good agricultural and environmental condition, without having to implement produc-

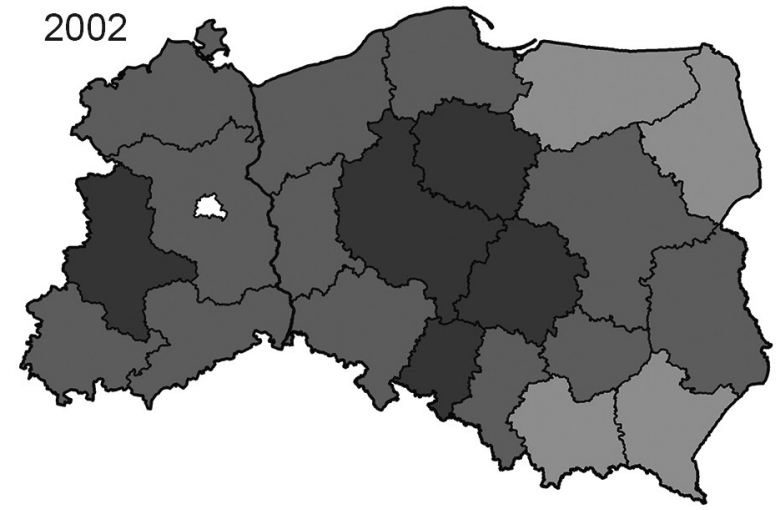

$<50$

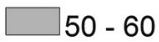

$\square 50-60$

$60-70$

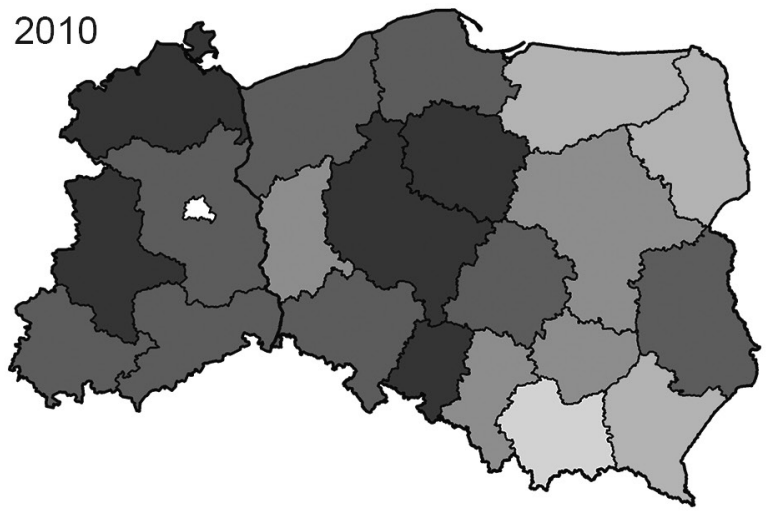

$70-80$

$>80$

Fig. 2. Share of arable land in the total area in voivodeships in Poland and Länder in East Germany in 2002 and 2010 (\%) Source: authors' own calculation based on German 2011 data and Polish 2002 and 2010 Agricultural Censuses 
tion functions but following the requirements of environmental protection (Fig. 2).

Over the years 2002-2010, in the eastern Länder of Germany the share of farmland in the total area decreased by $1.6 \%$, with the exception of Saxony-Anhalt, where this share increased by $0.2 \%$. The land-use structure recorded an increase in the area of arable land by $0.5 \%$, the largest increase being recorded in Mecklenburg, where this area increased by $0.8 \%$. In the other three eastern Länder a slight decrease in arable land area was observed.

\section{Changes in the agrarian structure}

Poland's agrarian structure is characterised by excessive fragmentation, which is a lot more significant compared with East Germany. This means that most farms cannot generate the economic strength which would allow them to adjust to the new conditions of agricultural commodity markets in the European Union.

\section{Historical background}

In the socialist period Poland's agricultural economy was influenced by doctrinal factors. The preferred model of agriculture was the socialised one in the form of state-owned and cooperative farms and planned agricultural production, which in general satisfied the domestic market for food. Industrialisation processes intensified rural-urban migration, reduced overcrowding in rural areas, and created conditions for land concentration. At the same time, however, the socialist agricultural policy discriminated against private large-scale farms leading to their recapitalisation and land fragmentation. Small farms were conducive to the spread of second occupations among farmers and reduced charges for compulsory deliveries, the size of which was dependent on the size of the farm. This led to an increase in the total number of farms of up to 5 ha by $9 \%$ (1950-1960). The introduction of "area standards" for basic farms at 8 ha and establishing the maximum size of a farm at 15-20 ha in the 1960s did not favour land concentration and significantly limited the turnover of agricultural land. In the 1970s, a number of measures were taken under the national agricultural policy to improve the agrarian structure, such as the abolition of compulsory deliveries, a reduction of the land tax, and legal changes enabling granting pension benefits to farmers (1974) in exchange for the transfer of their land to the State Land Fund (SLF), which also allowed transferring the farm to a successor (1977). The SLF-controlled agricultural land was given primarily to state and cooperative farms; very little was sold to individual farmers. In the 1980s the available farmland was primarily in use by socialised agriculture (Instrumenty ... 2009). Despite the fact that the socialised economy was favoured and the conditions for the purchase of production means for socialised farms were better, the number of individually held farms and the level of land concentration in this sector remained stable. Although in the years 1950-1989 the share of socialised farms increased from $10 \%$ to $24 \%$, private farms remained a dominant organisational form in Polish agriculture.

Until July 1990, the economy of East Germany was conducted according to the principles of the socialist economy. Individual farms were liquidated together with their animal husbandry, field bounds and access roads, which led to permanent changes in the rural cultural landscape (JezierskaThöle 2010). In the years 1945-1952, a land reform was carried out in the Soviet occupation zone (the former East Germany). Its purpose was fragmenting large farms (Junker) for "refugees from the East", leasing the land to "new" farmers and creating garden plots (Hoffman 1993: 45). The land reform was aimed at the owners of large farms of over 100 ha (Brückner 1992: 11). The right to acquire land was granted mainly to farmers and displaced people from the east. Their proportion in the management of agricultural land was $42.6 \%$ and $34.9 \%$, respectively. During this period, the average size of a farm was 7.8 ha. The second phase of collectivisation took place in the years 1952-1960. The processes of land concentration was designed to increase agricultural production through the introduction of machinery to the production cycle. In the first period of the formation of cooperatives the largest group (78\%) was that of "new" farmers who received land through the post-war land reform, and the smallest group, that of pre-war farmers $(9 \%)$. 
The next stage of the transformation of the agrarian structure (1960-1968) was consolidation and cooperation of farms as well as concentration of production. Industrialisation of agriculture after the year 1968 was the last stage in Marx's theory of nationalisation. Its aim was to create large specialised farms with intensive agricultural production. Ownership of the land was respected, but it was part of the salary. In this period, the processes of land concentration, specialisation into crop or animal production, and intensification of agricultural production took place. The effect was the emergence of large-scale farms specialised in crop and livestock production (Ahrends, Hoell 1989: 61). The state sector consisted of the following units: agricultural cooperatives (LPG), state farms (VEG), and horticultural cooperatives (GPG).

The unification of Germany in July 1990 into a single state launched a series of measures to improve the economy of the agricultural sector, which included the adoption of a new privatisation law and the introduction of a financing system under the EU agricultural policy. The ownership transformation in the new German Länder included both privatisation and re-privatisation of state property, as well as its municipalisation. At the core of the privatisation of agriculture was the implementation of political goals, i.e. the elimination of the over-extended public sector and adaptation of farms to the new legal rules in force in the EU. The Privatisation and Reorganisation of State-Owned Enterprises Act was issued on 13 July 1990. Its introduction was preceded by creating the Trust Department (Treuhandanstalt) on 1 June 1990, which dealt with the transformation of enterprises into joint-stock companies, and conducted privatisation and re-privatisation (Janzen, Sadler 1993). In 1989, only 10-20\% of agricultural land in the hands of cooperatives had owners. In this situation, the then Minister of Food, Agriculture and Forestry commissioned the transformation of these lands into farms. As holdings in the former GDR were large, the Minister set the minimum acreage for those farms at 200 ha with an appropriate amount of livestock (e.g. 50-100 head of cattle and 700 pigs) (Grykień 2004: 54). The acquisition of land by workers of cooperative farms led to an increase in the number of farms of 1 to 10 ha. In the 1990s polarisa- tion of farms occurred (as in Poland today). It was characterised by high proportions of small farms (2-15 ha) and very large farms (over 1,000 ha). In 1991, the average farm size was 346 ha.

\section{Recent trends in the size of farms}

In 2010, the total number of farms (over 1 ha of agricultural land) in Poland was 1,562,605; compared against 2002, it had decreased by $20 \%$. According to most experts, the improvement of the agrarian structure is very slow because the rate and nature of changes are multi-directional. A spatial analysis of changes in the number of farms shows that their largest decrease occurred in southern Poland in Opole (32\%), Śląsk (30\%), Subcarpathia (26.9\%) and Lubuska Land (26.6\%) voivodeships, where it was accompanied by an increase in the average farm size. The smallest decrease was recorded in Wielkopolska (11.3\%), Podlasie (13.8\%) and Kujavia-Pomerania $(14.7 \%)$. The average annual rate was not high and amounted to $2.5 \%$ for the entire country.

The agrarian structure of Polish agriculture is more fragmented than in Germany. Very small farms of up to 5 ha, which make up $55.2 \%$ of the total number of holdings in Poland, do not have the conditions to use labour effectively and ensure an adequate income to support the owners' families and the development of the farm. Moreover, such farms are not able to compete on the European market. Poland's agriculture is dominated by the family ownership model, which applies to holdings possessing $90 \%$ of agricultural land. To a large extent, small farms in Poland act as a life buoy in the event of loss of other sources of income. On the other hand, land ownership brings social prestige and is a good investment (Jezierska-Thöle 2012).

In 2010, the average area of agricultural land owned by Polish farms was 9.8 ha, but varied spatially: from 3.8 ha in Małopolska and 4.4 ha in Subcarpathia to 29.8 ha in West Pomerania and 23.7 ha in Warmia-Mazuria. In comparison with 2002, the average farm size in the country increased by 1.4 ha.

Changes in the average farm size by acreage group show an increase by 0.1 ha in the case of small farms ( 1 to $5 \mathrm{ha}$ ). A decrease in the average size of an agricultural holding was observed 


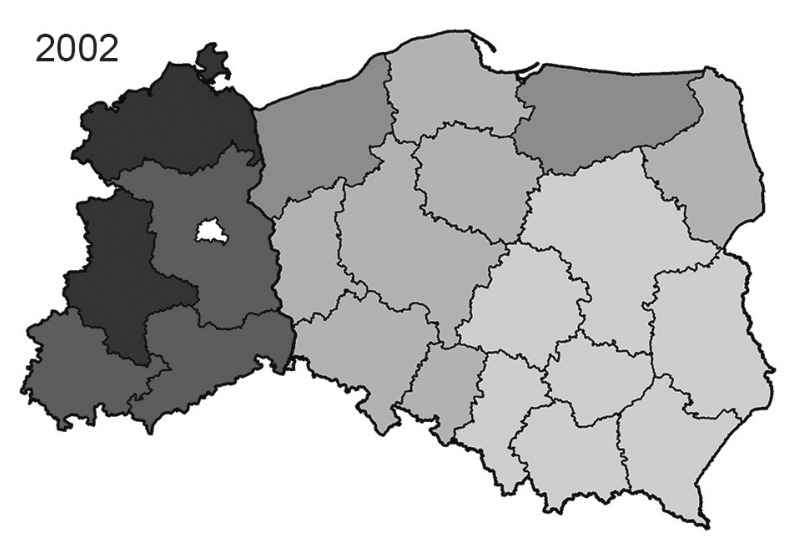

$<10 \square 10-20$

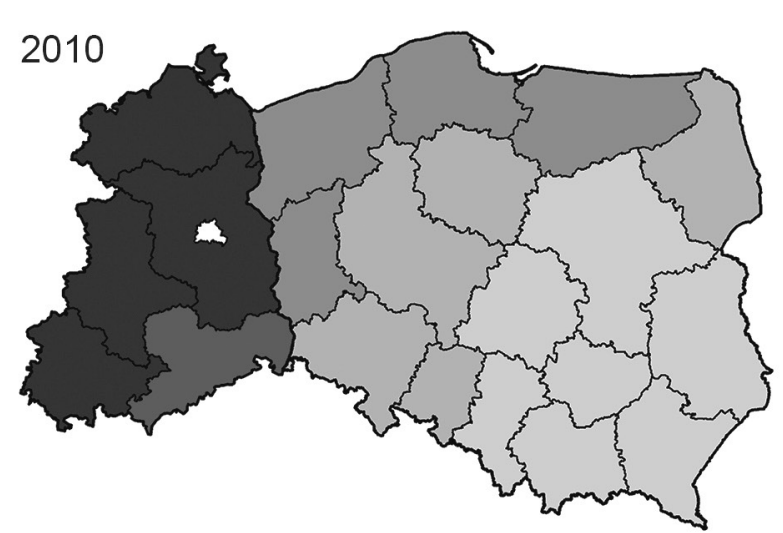

$20-40$

$100-200$

$>200$

Fig. 3. Average farm size in 2002 and 2010 (ha)

Source: authors' own calculation based on German 2011 data and Polish 2002 and 2010 Agricultural Censuses

in the case of large farms of over 50 ha (by 48.1 ha) and those from 20 to 50 ha (by 0.8 ha). Since a vast majority of agricultural land is in the hands of small and medium-sized farms, Poland's agriculture is characterised by low labour and capital productivity. It is therefore necessary to continue land concentration processes leading to the emergence of a distinct group of farms able to compete with EU agriculture (Fig. 3).

In 2010, the largest group of farms (55.2\%) was that of units with 1-5 ha agricultural land. Compared against 2002, there was a decrease in their proportion by $3.5 \%$. The largest increase, by $1.3 \%$, occurred in the share of farms from 20 to 50 ha. The share of large farms over 50 ha increased by $0.7 \%$, of those of $5-10$ ha - by $0.68 \%$, and those of $10-20$ ha - by $0.75 \%$ (Fig. 4).

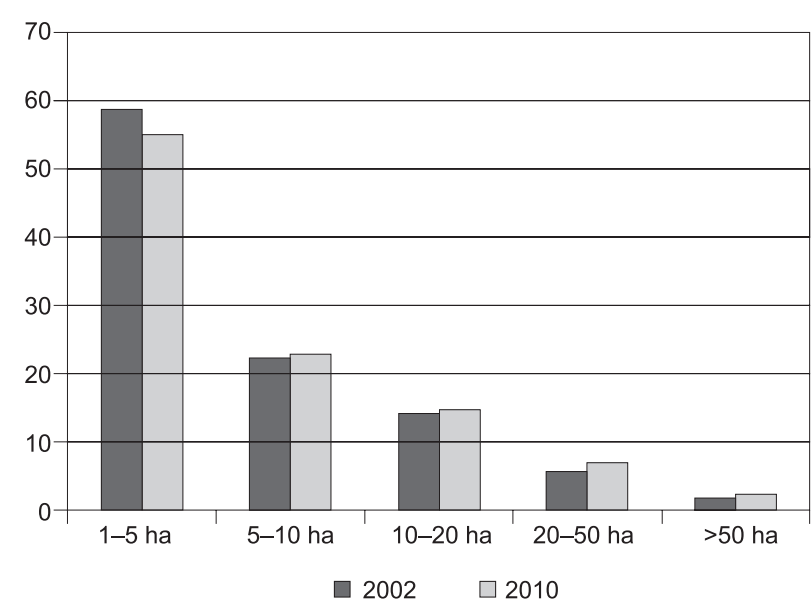

Fig. 4. Changes in the share of farms (of more than 1 ha) in the particular size groups in Poland in 2002 and 2010 (\%) Source: authors' own calculation based on 2011 data from rural areas in Poland and 2002 and 2010 Agricultural Censuses
A spatial analysis of the percentage of farms in each acreage group by voivodeship shows large spatial variations. In 2010, the largest proportion of small farms (1-5 ha of arable land) - over $80 \%$ - was recorded in Małopolska and Subcarpathia. A relatively high proportion of small farms was recorded in Silesia (77.5\%). Their smallest share was recorded in the northern voivodeships of Podlasie (30.1\%), Kujavia-Pomerania (32.1\%), Pomerania $(37.7 \%)$, and Wielkopolska (38.4\%).

The second largest group of farms was that of those from 5 to 10 ha $(22.5 \%)$, most of them located in central voivodeships of Poland: Łódź (30.5\%), Mazovia (28.5\%) and Lublin (27.8\%). In the group of medium-sized farms (10-20 ha) the highest share was recorded in the belt of northern voivodeships: Podlasie (28.9\%), Kujavia-Pomerania $(25.2 \%)$, Warmia-Mazuria $(25.6 \%)$, and Wielkopolska (23.5\%). Their share was $23.5 \%$, while that of large farms (20-50 ha) was $6.2 \%$. The highest proportion of large farms was recorded in the northern belt: Warmia-Mazuria (19.4\%), Kujavia-Pomerania (14.9\%) and Podlasie $(13.9 \%)$, and in Opole voivodeship (14.6\%) in southern Poland. In the group of very large farms (over 50 ha) the highest share was recorded in the former Prussian partition, and in the regions of a large proportion of socialised agriculture in the previous period, i.e. West Pomerania (9.8\%), Warmia-Mazuria (7.1\%), Lubuska Land (6.1\%), Pomerania $(4.8 \%)$ as well as Opole $(5.0 \%)$ and Lower Silesia (4.4\%).

The changes in the agrarian structure of farms in East Germany had a different character be- 
cause of its different economic conditions in the late 1980s. In the former East Germany this structure was dominated by large-scale cooperative and state-owned farms, while private farms accounted for a small share, viz. $5.5 \%$ of the total area. In 2010, the number of farms in the eastern Länder of Germany was 24,455. Compared against 2002 , it decreased by $18.7 \%$. A spatial analysis of changes in the number of farms shows that the largest decline occurred in Thuringia - by $27.8 \%$, and Saxony - by $22.7 \%$ (Fig. 5). At the same time, these Länder recorded the fastest growth in the average size of agricultural holdings (by $37 \%$ and $29 \%$, respectively).

The overall decline in the number of farms in East Germany was accompanied by an increase in their average size from 185 ha in 2002 to 227 ha in 2010 , i.e. by $23 \%$. The highest average farm size is still recorded in Mecklenburg (285 ha) and Brandenburg (278 ha), and the smallest in Saxony (145 ha). In 2010 the largest group of agricultural holdings (37.8\%) included very large farms (over $50 \mathrm{ha}$ ). Another group consisted of medium-sized farms (10-20 ha) (12.4\%). The share of small farms in the total number of holdings accounted for only $9.0 \%$. The proportion of farms by size group was inversely proportional to their share in Poland (Fig. 5).

A comparative analysis of changes in the share of farms in each area group in Poland and East Germany over the years 2002-2010 shows many similarities. The largest decrease was recorded in the group of small farms, although in Germany

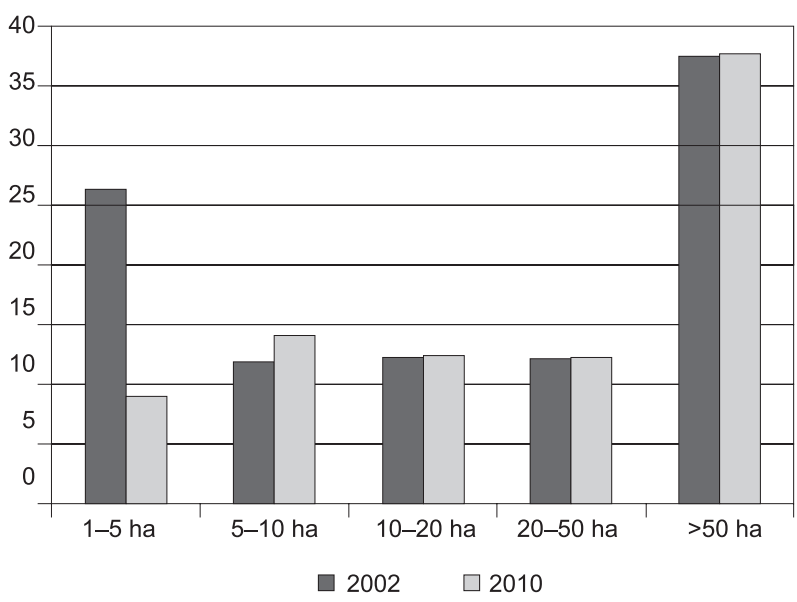

Fig. 5. Changes in the share of farms (of more than 1 ha) in the particular size groups in Germany in 2002 and 2010 (\%) Source: authors' own calculation based on German 2011 data and Polish 2002 and 2010 Agricultural Censuses the drop was steeper and amounted to $17.3 \%$. A large decline in the number of German farms also resulted from a change in the definition of a farm in the agricultural census: it covered farms of 5 ha and over. Smaller farms (2-5 ha) were included in the census under specific conditions, e.g. if they conducted animal husbandry (50 pigs, 10 livestock units of cattle) (Situationsbericht 2012: 92).

\section{Recent trends in crop and livestock production}

As a result of the implementation of the Common Agricultural Policy, there has been a change in land use and in the direction and volume of agricultural production in Poland. Changes in crop and livestock production were determined on the basis of the yields of major crops and livestock density. A comparative analysis of the sown area in Poland in the years 2002-2010 shows two trends. Total sown area decreased from 10.8 million ha to 10.4 million ha. The decrease was mainly recorded on very small farms $(51.6 \%)$, while it grew for large farms of 30-50 ha (14\%) and very large ones of over 50 ha (18\%) (Raport ... 2010).

Favourable meteorological conditions occurring during the growing season and the increase in the sown area of major agricultural crops resulted in higher yields despite lower consumption of fertilisers (Obszary ... 2011). In the years 2002-2010 there was an overall increase in agricultural yields of the main crops. The growth in total cereal yields $(9 \%)$ was the highest. In terms of the spatial distribution, the highest yield was reached in voivodeships where large farms dominated, i.e. Opole (51 dt/ha), Lower Silesia (47 dt/ ha), West Pomerania (44 dt/ha), and Warmia-Mazuria (41 dt/ha). The lowest yield was recorded in those with a fragmented agrarian structure, i.e. Świętokrzyska Land ( $26 \mathrm{dt} / \mathrm{ha})$, Podlasie (29 $\mathrm{dt} / \mathrm{ha}$ ), and Mazovia (28 dt/ha). Yields were 6\% lower in two voivodeships: Świętokrzyska Land and Silesia (Fig. 6).

Different development trends were noted in rape crops. On the one hand, an increase in yields was recorded in 10 voivodeships, including Lubuska Land where it increased from 16 to $23 \mathrm{dt} /$ ha, i.e. by $42 \%$. On the other hand, six 

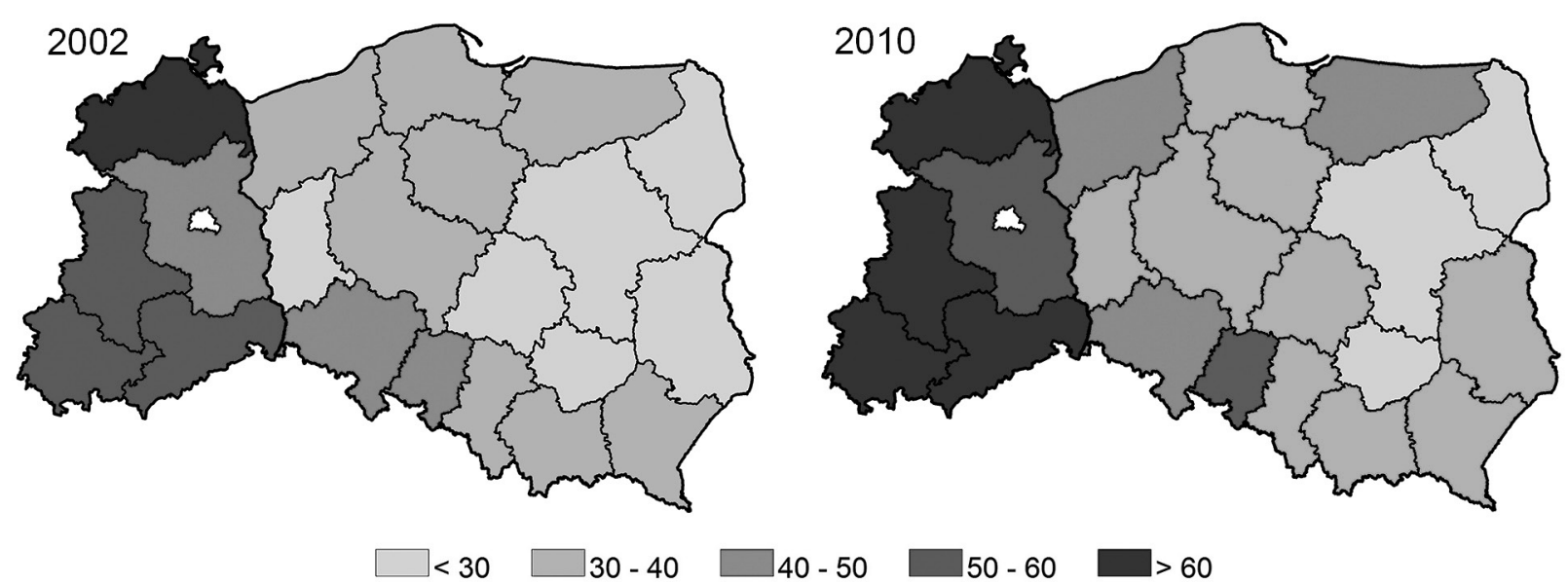

Fig. 6. Cereal yields in Poland and East Germany in 2002 and 2010 (dt/ha) Source: authors' own calculation based on German 2011 data and Polish 2002 and 2010 Agricultural Censuses

voivodeships recorded reduced yields, including Silesia from 23 to $18 \mathrm{dt} /$ ha $(-23 \%)$. Similar development trends were noted in potato crops, where a decline occurred in six voivodeships, e.g. in Małopolska from 184 to $146 \mathrm{dt} / \mathrm{ha}(-21 \%)$. The largest increase in the yield was recorded in Lublin voivodeship, from 189 to $266 \mathrm{dt} / \mathrm{ha}(41 \%)$.

A comparative analysis of Polish and German yields shows large disparities. The largest differences occur in total cereal yields: the average for Poland ( $36 \mathrm{dt} / \mathrm{ha}$ ) amounts to a mere $54 \%$ of the average for Germany (67 dt/ha). The highest yield obtained in Opole voivodeship (51 ha/dt) is the lowest value recorded in Germany in the federal state of Brandenburg (50.8 dt/ha). The second largest value, recorded in Lower Silesia (48 dt/ha), was the lowest in Brandenburg (48 dt/ha) in 2002 (Fig. 7). Such wide disparities result from the fragmented agrarian structure, a decreased level of fertilisation, and the use of less efficient seed, but also from different soil and climatic conditions. A similar situation was observed in potato yields, where the average value for Poland (212 dt/ha) accounted for 53\% of the mean for Germany (399 dt/ha). The maximum yield in Opole voivodeship (251 dt/ha) represents $63 \%$ of the average yield in Germany. A smaller difference was reported in the sugar beet yield, where the national average in Poland (468 dt/ha) accounts for $76 \%$ of the German figure (616 dt/ha). The highest value in Poland (539 $\mathrm{dt} / \mathrm{ha})$, recorded in Lower Silesia, is higher than the lowest value obtained in Mecklenburg (527 $\mathrm{dt} / \mathrm{ha}$ ) (Table 2).

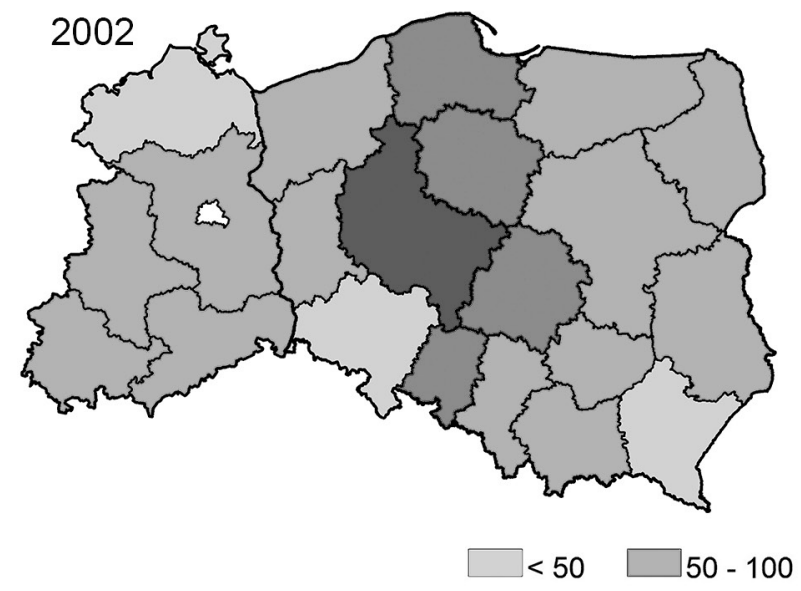

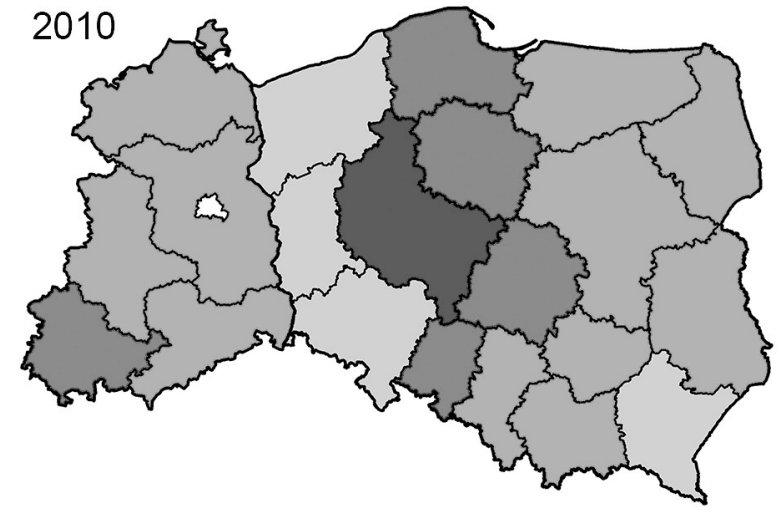

$100-200 \square>200$

Fig. 7. Pig population per 100 ha of agricultural land in Poland and East Germany in 2002 and 2010 Source: authors' own calculation based on German 2011 data and Polish 2002 and 2010 Agricultural Censuses 
Table 2. Dynamics of change in the yields of the main crops in Poland and East Germany

\begin{tabular}{|c|c|c|c|c|c|c|c|c|c|c|c|c|}
\hline \multirow[t]{2}{*}{ Länder / Voivodeship } & \multicolumn{3}{|c|}{ Cereal yield (dt/ha) } & \multicolumn{3}{|c|}{ Potato yield (dt/ha) } & \multicolumn{3}{|c|}{$\begin{array}{c}\text { Sugar beet yield } \\
\text { (dt/ha) }\end{array}$} & \multicolumn{3}{|c|}{$\begin{array}{l}\text { Oilseed yield } \\
\text { (dt/ha) }\end{array}$} \\
\hline & 2002 & 2010 & $2002=100$ & 2002 & 2010 & $2002=100$ & 2002 & 2010 & $2002=100$ & 2002 & 2010 & $2002=100$ \\
\hline Brandenburg & 48 & 51 & 105 & 301 & 321 & 106 & 493 & 566 & 115 & 26 & 37 & 144 \\
\hline $\begin{array}{l}\text { Mecklenburg-Vorpom- } \\
\text { mern }\end{array}$ & 65 & 67 & 103 & 362 & 313 & 86 & 488 & 527 & 108 & 32 & 40 & 126 \\
\hline Saxony & 56 & 64 & 114 & 349 & 397 & 114 & 554 & 656 & 118 & 28 & 39 & 136 \\
\hline Saxony-Anhalt & 60 & 70 & 117 & 405 & 413 & 102 & 505 & 591 & 117 & 27 & 41 & 152 \\
\hline Thuringia & 59 & 63 & 106 & 396 & 370 & 93 & 544 & 615 & 113 & 29 & 38 & 129 \\
\hline Łódź & 27 & 31 & 115 & 176 & 210 & 119 & 365 & 421 & 115 & 22 & 24 & 106 \\
\hline Mazovia & 26 & 28 & 108 & 183 & 219 & 120 & 439 & 449 & 102 & 22 & 19 & 86 \\
\hline Małopolska & 31 & 31 & 100 & 184 & 146 & 79 & 438 & 283 & 65 & 24 & 21 & 86 \\
\hline Silesia & 34 & 32 & 94 & 204 & 172 & 84 & 506 & 452 & 89 & 23 & 18 & 78 \\
\hline Lublin & 30 & 32 & 105 & 189 & 266 & 141 & 433 & 479 & 111 & 23 & 22 & 98 \\
\hline Subcarpathia & 31 & 32 & 101 & 203 & 188 & 93 & 434 & 381 & 88 & 19 & 22 & 115 \\
\hline Podlasie & 24 & 29 & 120 & 185 & 203 & 110 & 372 & 472 & 127 & 19 & 24 & 123 \\
\hline Świętokrzyska Land & 28 & 26 & 94 & 168 & 164 & 98 & 436 & 516 & 118 & 21 & 24 & 112 \\
\hline Lubuska Land & 30 & 36 & 122 & 213 & 202 & 95 & 490 & 535 & 109 & 16 & 23 & 142 \\
\hline Wielkopolska & 35 & 38 & 108 & 198 & 231 & 117 & 471 & 490 & 104 & 21 & 24 & 115 \\
\hline West Pomerania & 35 & 44 & 125 & 219 & 232 & 106 & 428 & 459 & 107 & 21 & 26 & 124 \\
\hline Lower Silesia & 44 & 47 & 107 & 216 & 207 & 96 & 413 & 539 & 131 & 22 & 21 & 95 \\
\hline Opole & 46 & 51 & 110 & 225 & 251 & 112 & 433 & 499 & 115 & 25 & 24 & 96 \\
\hline Kujavia-Pomerania & 36 & 38 & 106 & 204 & 229 & 112 & 455 & 479 & 105 & 25 & 29 & 113 \\
\hline Pomerania & 34 & 37 & 107 & 246 & 246 & 100 & 507 & 514 & 101 & 20 & 23 & 116 \\
\hline Warmia-Mazuria & 31 & 41 & 133 & 193 & 233 & 121 & 466 & 518 & 111 & 20 & 21 & 107 \\
\hline
\end{tabular}

Source: authors' own calculation based on German 2011 data and Polish 2002 and 2010 Agricultural Censuses

Over the analysed period, Poland recorded a decrease in pig population per 100 ha of agricultural land from 94 to 87 units $(-7 \%)$. For comparison, in Germany during the same period pig density increased from 154 to 161 units (5\%). A similar trend of growth was observed in five voivodeships in Poland: Łódź, Silesia, Wielkopolska, Podlasie, and Świętokrzyska Land (growth by 6 to $11 \%)$. The highest pig density was recorded by Wielkopolska (269 units/100 ha) and Kujavia-Pomerania (165 units/100 ha). However, in Lower Silesia, Lubuska Land, West Pomerania and Subcarpathia pig density did not exceed 50 units per 100 ha of agricultural land. The average density for Poland constituted half of the average density for Germany, but was higher than the average for East Germany (78 units/100 ha) (Fig. 7).

An opposite trend was observed in the case of changes in cattle units per 100 ha of agricultural land. In the years 2002-2010 cattle density in Poland increased from 28 to 33 cattle units per
100 ha (19\%), while in Germany a decrease was recorded in all the regions, from 82 to 76 cattle units per 100 ha $(-8 \%)$. In Poland, only three voivodeships recorded a downward trend: Subcarpathia $(-23 \%)$, Małopolska $(-7 \%)$, and Lower Silesia $(-6 \%)$. The highest cattle density, recorded in Podlasie (82 units/100 ha), was higher than the average for Germany and twice as high as the average for the east German Länder (44 units / 100 ha). The average value of cattle units per 100 ha for Poland constituted $78 \%$ of this value for Germany. For 10 years sheep density in Poland remained at the same level (2 units/100 ha) and was only $15 \%$ of that for Germany. The highest value of sheep density noted in Małopolska (11 units/100 ha) was equal to the East German average. At the same time, all the eastern states of Germany noted a downward tendency in the sheep population, while in Poland a decrease was recorded in only five voivodeships. 


\begin{tabular}{|c|c|c|c|c|c|c|c|c|c|c|c|c|c|}
\hline \multirow{4}{*}{ 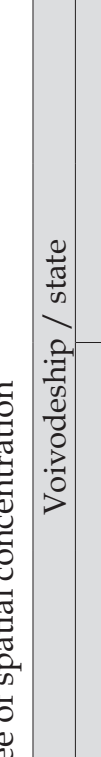 } & \multirow{2}{*}{ 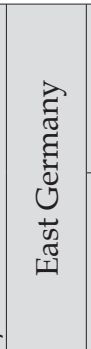 } & 올 & 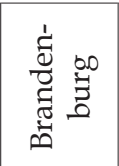 & 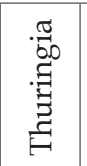 & 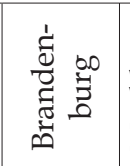 & 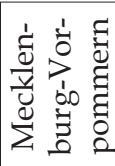 & 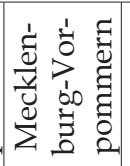 & 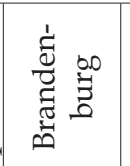 & 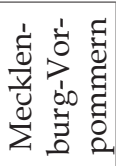 & 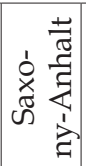 & 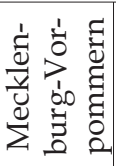 & 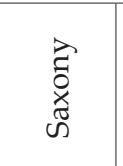 & 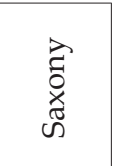 \\
\hline & & ণิ & 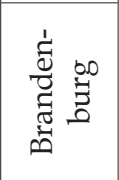 & 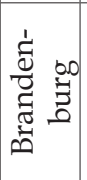 & 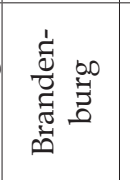 & 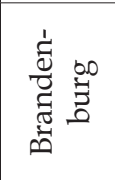 & 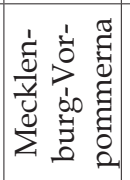 & 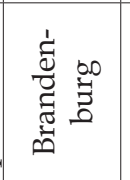 & $\begin{array}{l}\vec{D} \\
\text { ठ } \\
\text { 心 }\end{array}$ & 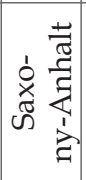 & 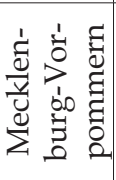 & 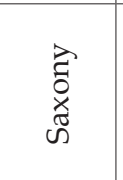 & $\begin{array}{l}\overrightarrow{0} \\
\text { 心. } \\
\text { 心 }\end{array}$ \\
\hline & \multirow{2}{*}{$\begin{array}{l}\overrightarrow{0} \\
\frac{\pi}{0} \\
0\end{array}$} & $\begin{array}{l}\text { 여 } \\
\text { ते }\end{array}$ & 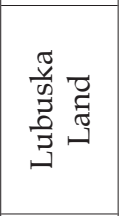 & $\begin{array}{l}\frac{\pi}{\pi} \\
\frac{\pi}{0} \\
0 \\
\frac{0}{0} \\
\frac{\pi}{\pi}\end{array}$ & 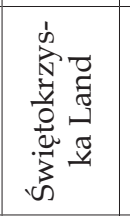 & $\begin{array}{l}\frac{\pi}{\tilde{w}} \\
\frac{a}{0} \\
\frac{0}{0} \\
\frac{\pi}{\pi}\end{array}$ & $\begin{array}{l}\frac{\pi}{v} \\
\frac{\pi}{0} \\
0 \\
\frac{0}{0} \\
\frac{\pi}{\pi}\end{array}$ & 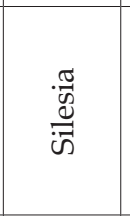 & 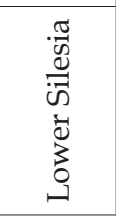 & 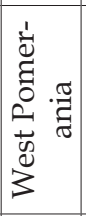 & 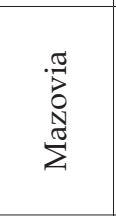 & $\begin{array}{l}\frac{\pi}{\pi} \\
\frac{\pi}{0} \\
0 \\
\frac{0}{0} \\
\frac{\pi}{2}\end{array}$ & 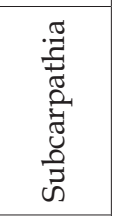 \\
\hline & & స్రి & 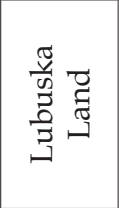 & $\begin{array}{l}\frac{0}{0} \\
\frac{\pi}{0} \\
0 \\
0 \\
0\end{array}$ & $\begin{array}{l}\frac{0}{0} \\
\frac{\pi}{\pi} \\
\overline{0} \\
0 \\
0\end{array}$ & 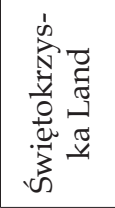 & 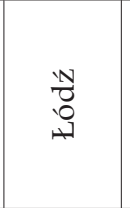 & 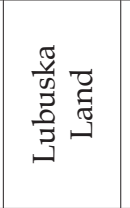 & 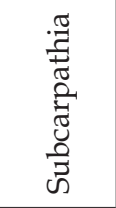 & 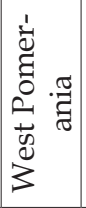 & 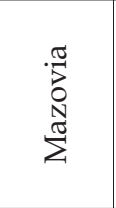 & $\begin{array}{l}\frac{\pi}{0} \\
\frac{\pi}{0} \\
0 \\
\frac{0}{0} \\
\frac{\pi}{\pi}\end{array}$ & 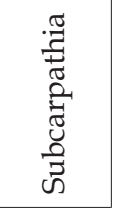 \\
\hline \multirow{4}{*}{ 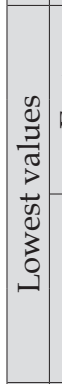 } & \multirow{2}{*}{ 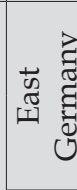 } & 옹 & $\stackrel{\leftrightarrow}{\dot{F}}$ & $\stackrel{\Im}{\hat{\Sigma}}$ & $\begin{array}{l}\infty \\
\dot{1} \\
\text { in }\end{array}$ & $\begin{array}{l}\stackrel{20}{\mathrm{i}} \\
\stackrel{\mathrm{n}}{ }\end{array}$ & 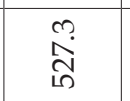 & ले & $\begin{array}{l}\infty \\
\stackrel{\infty}{\circ}\end{array}$ & ָे. & ণु & $\underset{\mathrm{J}}{\mathrm{G}}$ & $\hat{m}$ \\
\hline & & సิ & के & $\stackrel{\llcorner}{\stackrel{n}{~}}$ & $\begin{array}{l}\text { Ny } \\
\text { o f }\end{array}$ & Na & 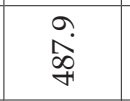 & $\begin{array}{l}\infty \\
\text { வnं }\end{array}$ & $\begin{array}{l}\stackrel{\circ}{\circ} \\
\stackrel{4}{4}\end{array}$ & $\begin{array}{l}\text { ले } \\
\text { ले }\end{array}$ & $\bigcap_{\infty}^{\infty}$ & $\begin{array}{l}\infty \\
\stackrel{\infty}{0}\end{array}$ & $\stackrel{L}{+}$ \\
\hline & & 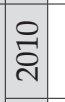 & $\begin{array}{l}\text { तี } \\
\text { లై }\end{array}$ & $\hat{\partial}$ & $\begin{array}{l}\text { ڤેे } \\
\text { ते }\end{array}$ & \begin{tabular}{l}
0 \\
İ \\
\multirow{1}{*}{}
\end{tabular} & $\begin{array}{l}0 \\
\text { लें } \\
\text { वें }\end{array}$ & $\begin{array}{l}\stackrel{0}{\infty} \\
\stackrel{\infty}{\sim}\end{array}$ & $\stackrel{\sim}{\vec{\infty}}$ & 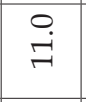 & $\stackrel{10}{\circ}$ & $\underset{+}{\infty}$ & ث̀. \\
\hline & 寄 & స్ & ले & : & $\stackrel{\sim}{+}$ & $\begin{array}{l}\stackrel{0}{0} \\
\stackrel{0}{0} \\
\stackrel{0}{-1}\end{array}$ & 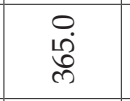 & $\underset{\sim}{3}$ & $\stackrel{3}{\vec{F}}$ & $\begin{array}{l}\stackrel{\circ}{\circ} \\
\stackrel{-}{r}\end{array}$ & $\stackrel{0}{0}_{0}^{\circ}$ & $\stackrel{\vec{H}}{+}$ & $\stackrel{\infty}{\stackrel{\infty}{d}}$ \\
\hline \multirow{2}{*}{\multicolumn{2}{|c|}{ : }} & & 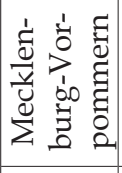 & 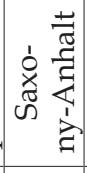 & 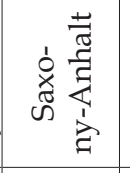 & 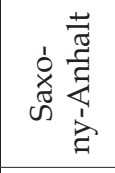 & $\begin{array}{l}\overrightarrow{\hat{D}} \\
\text { x. } \\
\text { 心 }\end{array}$ & 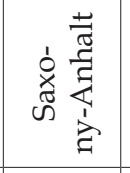 & 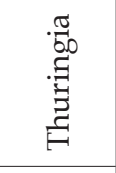 & 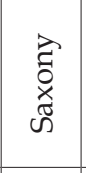 & 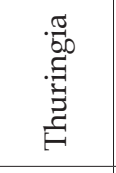 & 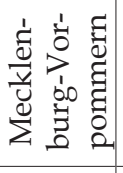 & 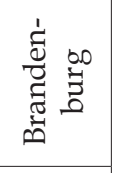 \\
\hline & & ๙ิ & 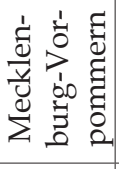 & 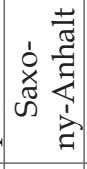 & 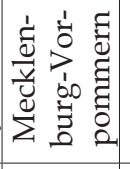 & 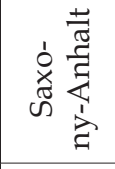 & 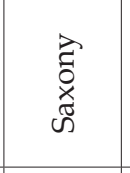 & 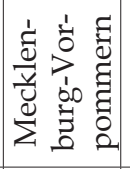 & 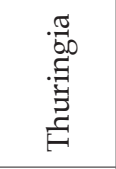 & $\begin{array}{l}\vec{\Xi} \\
\text { 荡 } \\
\omega\end{array}$ & 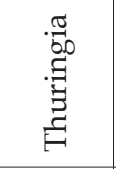 & 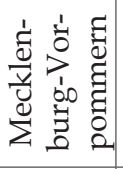 & 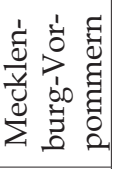 \\
\hline \multirow{2}{*}{ 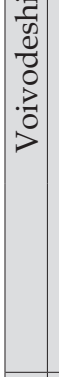 } & \multirow{2}{*}{$\begin{array}{l}0 \\
\overline{0} \\
0 \\
0\end{array}$} & 量 & 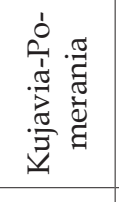 & $\begin{array}{l}\frac{0}{0} \\
0 \\
0\end{array}$ & 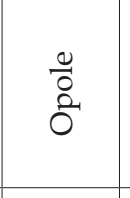 & 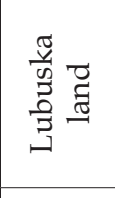 & 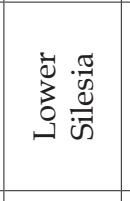 & 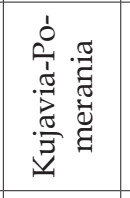 & 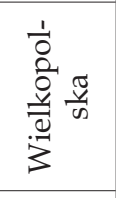 & 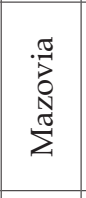 & $\begin{array}{l}\frac{\pi}{\pi} \\
\frac{\pi}{0} \\
0 \\
\frac{0}{0} \\
\frac{\pi}{\pi}\end{array}$ & 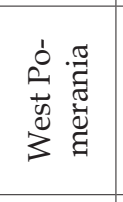 & 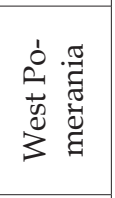 \\
\hline & & ઠิ & 㻤 & 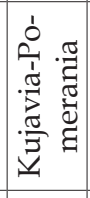 & $\begin{array}{l}\frac{0}{0} \\
0 \\
0\end{array}$ & 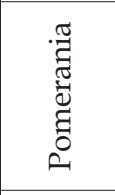 & 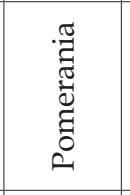 & $\begin{array}{l}\frac{0}{0} \\
0\end{array}$ & 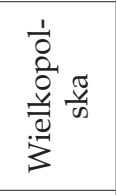 & $\begin{array}{l}\frac{0}{0} \\
\frac{\pi}{0} \\
\overline{0} \\
0 \\
0\end{array}$ & $\begin{array}{l}\frac{\pi}{\frac{\pi}{0}} \\
\frac{0}{0} \\
\frac{0}{0} \\
\frac{0}{\pi} \\
\frac{\pi}{2}\end{array}$ & 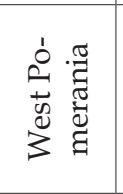 & 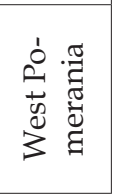 \\
\hline \multirow{4}{*}{ 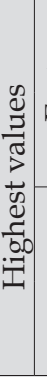 } & \multirow{2}{*}{ 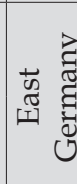 } & 空 & ஜ். & $\begin{array}{l}40 \\
\infty \\
\infty\end{array}$ & $\begin{array}{l}0 \\
\ddot{0}\end{array}$ & 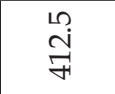 & 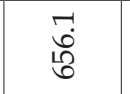 & $\begin{array}{l}\text { Ln } \\
\stackrel{+}{+}\end{array}$ & 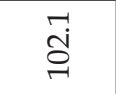 & $\begin{array}{l}\text { Nִ } \\
\text { 占 }\end{array}$ & $\stackrel{\sim}{\sim}$ & 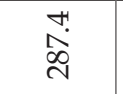 & 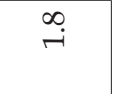 \\
\hline & & 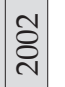 & ڤ్ర & $\begin{array}{l}0 \\
1 \\
\infty\end{array}$ & 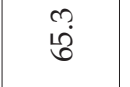 & 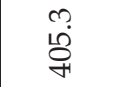 & $\begin{array}{l}\infty \\
\infty \\
10 \\
10\end{array}$ & $\stackrel{\text { ले }}{\text { के }}$ & ๙் & $\begin{array}{l}\text { ○. } \\
\text { in }\end{array}$ & ڤे & ڤై & $\vec{i}$ \\
\hline & \multirow{2}{*}{$\begin{array}{l}0 \\
0 \\
0 \\
0\end{array}$} & 염 & ஜุ & ஸุ & ஜे & $\begin{array}{l}\text { Oें } \\
\text { iें }\end{array}$ & ஜें & $\begin{array}{l}\stackrel{20}{0} \\
\infty \\
\sim\end{array}$ & $\begin{array}{l}\text { L } \\
\text { oे }\end{array}$ & $\underset{\infty}{\vec{i}}$ & $\stackrel{10}{\circ}$ & $\stackrel{\aleph}{\infty}$ & $\stackrel{f}{f}$ \\
\hline & & §ิ & $\begin{array}{l}0 . \\
\infty \\
\infty\end{array}$ & $\underset{\infty}{\stackrel{-}{\infty}}$ & भु & $\stackrel{\text { I }}{N}$ & 突 & $\begin{array}{l}\text { ڤn } \\
\text { வें }\end{array}$ & ثึ & 苞 & $\stackrel{\llcorner}{\Omega}$ & $\begin{array}{l}\circ \\
\text { ते }\end{array}$ & F \\
\hline & & & $\vec{x}$ & $x^{N}$ & $x^{n}$ & $x^{+}$ & $x^{10}$ & $x^{0}$ & $x$ & $x^{\infty}$ & $x^{a}$ & $x^{0}$ & $x^{7}$ \\
\hline
\end{tabular}




\section{Change in the level of agricultural development}

The analysed factors have a different range and spatial distribution. The highest and the lowest values of the analysed parameters are presented in Table 3 .

In 2010, the maximum values were usually recorded in Kujavia-Pomerania, Opole and West Pomerania, and the minimum ones in Małopolska. In the years 2002-2010 there was an increase of the maximum values, except for features $X_{1}$ and $X_{8^{\prime}}$ which means that the production capacity of individual voivodeships grew. At the same time, the minimum value of six of the analysed parameters decreased, indicating a widening developmental gap between the analysed administrative regions. In East Germany there was an increase in both maximum and minimum values, which indicates an increase in agricultural productivity and the levelling of differences in the development of the east German Länder. In 2010, the maximum values were reached four times by the Land of Saxony-Anhalt, and minimum ones by Mecklenburg.

In 2010, the highest value of the coefficient of variation $\mathrm{V}_{z^{\prime}}$ both in Poland and East Germany, was observed for feature $X_{9}$, which shows a considerable variation in the value along the string. In Poland, the standard deviation for five characteristics is more than $50 \%$ of the arithmetic mean, which indicates a very high spatial variation of the following features: livestock density $\left(X_{7^{\prime}}, X_{8^{\prime}}\right.$ $\left.X_{9}\right)$, average farm size $\left(X_{10}\right)$, and employment in agriculture $\left(X_{11}\right)$. These figures also point to large disparities in the development of individual regions. In East Germany spatial variation coefficients $\left(\mathrm{V}_{\mathrm{z}}<28 \%\right)$ were considerably smaller, indicating insignificant spatial differences in the analysed parameters and relatively uniform development of the eastern regions of Germany. A comparative analysis of the coefficients of spatial variation $\left(\mathrm{V}_{\mathrm{z}}\right)$ in Poland showed an increase in all the investigated features, with the largest recorded for $X_{2}$. This situation indicates deepening polarisation of the regions in terms of agricultural development. In East Germany, however, a slight increase in the $V_{z}$ values of six features was observed and a decrease in the other five. This means that the studied set of territorial units
Table 4. Coefficient of spatial variation (\%) in Poland and Germany

\begin{tabular}{|c|c|c|c|c|c|c|}
\hline \multirow{2}{*}{$\begin{array}{l}\text { Vari- } \\
\text { able }\end{array}$} & \multicolumn{4}{|c|}{ Coefficient of spatial variation $\left(\mathrm{V}_{7}\right)$} \\
\cline { 2 - 8 } & 2002 & 2010 & $2002=100$ & 2002 & 2010 & $2002=100$ \\
\hline$X_{1}$ & 14.31 & 17.88 & 125 & 10.54 & 10.04 & 95 \\
\hline$X_{2}$ & 8.29 & 16.5 & 199 & 4.19 & 3.88 & 93 \\
\hline$X_{3}$ & 18.09 & 19.61 & 108 & 10.8 & 11.55 & 107 \\
\hline$X_{4}$ & 10.07 & 15.46 & 153 & 11.45 & 12.31 & 107 \\
\hline$X_{5}$ & 9.09 & 13.84 & 152 & 5.84 & 8.23 & 141 \\
\hline$X_{6}$ & 11.06 & 11.53 & 104 & 8.49 & 3.74 & 44 \\
\hline$X_{7}$ & 61.01 & 70.03 & 115 & 25.79 & 25.84 & 100 \\
\hline$X_{8}$ & 42.07 & 55.07 & 131 & 20.13 & 21.8 & 108 \\
\hline$X_{10}$ & 55.78 & 57.23 & 103 & 30.92 & 24.84 & 80 \\
\hline$X_{11}$ & 55.52 & 56.47 & 102 & 29.86 & 27.4 & 92 \\
\hline
\end{tabular}

Source: authors' own calculation based on German 2011 data and Polish 2002 and 2010 Agricultural Censuses

is relatively little differentiated spatially (Table 4).

In order to analyse differences in agricultural development, the variables were standardised and Perkal's synthetic indicator $\left(\mathrm{W}_{\mathrm{i}}\right)$ calculated as an average of the eleven standardised features. On the basis of the $W_{i}$ value three types of agriculture were distinguished:

$$
\begin{aligned}
& \text { I type - progress }\left(\mathrm{W}_{\mathrm{i}}>0.25\right) \\
& \text { II type - stagnation }\left(-0.25<\mathrm{W}_{\mathrm{i}}<0.25\right) \\
& \text { III type - regression }\left(\mathrm{W}_{\mathrm{i}}<-0.25\right)
\end{aligned}
$$

Type I units, compared against the average rate of change, showed a tendency to progress (difference of $W_{i}$ values > 0.25). In 2010 in Poland there were five such voivodeships, or $31.2 \%$ of their total number. They were characterised by high values of the sub-indices used to analyse the level of agricultural development. The highest values $\left(\mathrm{W}_{\mathrm{i}}>0.60\right)$ were reached by Wielkopolska (0.76), Kujavia-Pomerania (0.75) and Opole (0.68). High rates $\left(\mathrm{W}_{\mathrm{i}}>0.25\right)$ were recorded in the north-western voivodeships, viz. Pomerania (0.30) and West Pomerania (0.29).

Type II units are characterised by stagnation (difference of the values of $-0.25<W_{i}<0.25$ ), which indicates an intensity of changes similar to average, showing either little progress or regression. In this group there were seven voivodeships, or $43.7 \%$ of their total number.

Type III units are those which, in comparison against the average rate of change, showed a tendency to regress (difference of the values of $W_{i}$ $<0.25)$. In 2010, the regressive nature of changes in agriculture was recorded in the voivodeships 

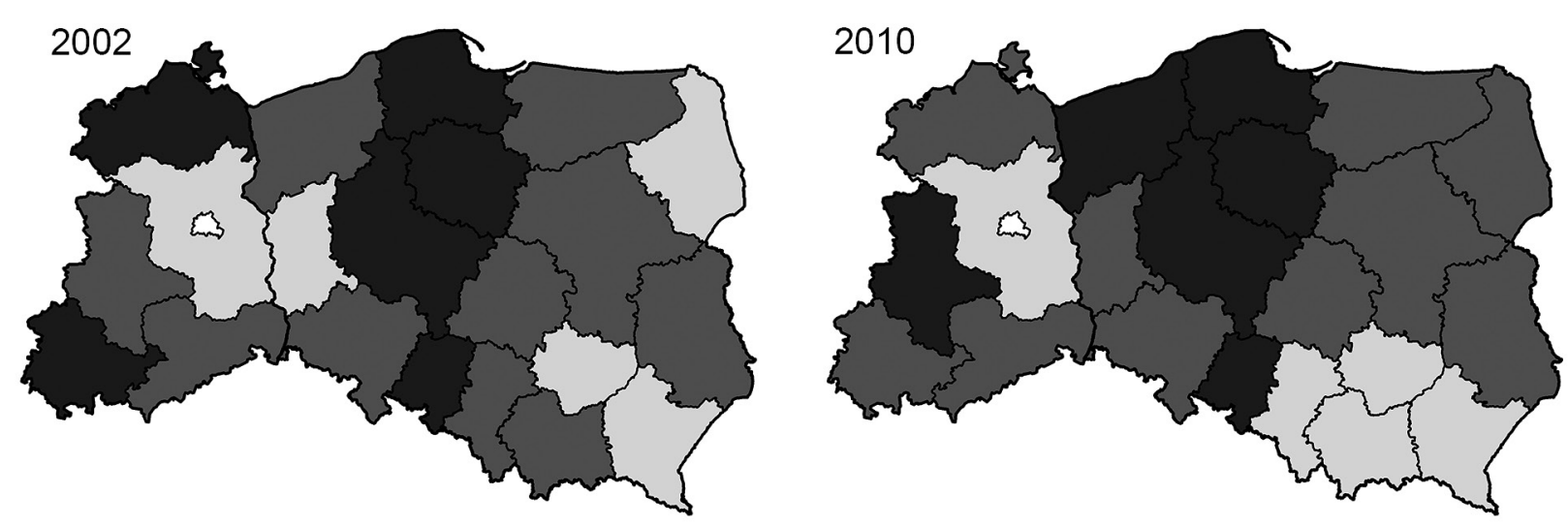

Fig. 8. Types of agricultural development in Poland and East Germany

type I - progress $\left(\mathrm{W}_{\mathrm{i}}>0.25\right)$, type II - stagnation $\left(-0.25<\mathrm{W}_{\mathrm{i}}<0.25\right)$, type III - regression $\left(\mathrm{W}_{\mathrm{i}}<-0.25\right)$

Source: authors' own calculation based on German 2011 data and Polish 2002 and 2010 Agricultural Censuses

located in the eastern and south-eastern parts of the country. The lowest value $\left(\mathrm{W}_{\mathrm{i}}<-0.50\right)$ was observed in two voivodeships: Silesia $(-0.57)$ and Świętokrzyska Land (-0.51), mainly due to a low value of the sub-indices characterising crop yields and livestock quantity (Fig. 8).

In the years 2002-2010, the number of voivodeships with a tendency to progress (type I) grew. However, the number of provinces showing evidence of regression had not changed, although two voivodeships, Małopolska and Silesia, shifted from the state of stagnation (type II) to that of progress (type III), mainly due to a decline in the values of their sub-indices $\mathrm{X}_{4^{\prime}} \mathrm{X}_{5^{\prime}} \mathrm{X}_{6^{\prime}} \mathrm{X}_{7^{\prime}} \mathrm{X}_{8}$. Podlasie and Lubuska Land moved from the state of regression (type I) to stagnation (type II). Their new position was primarily due to growth in crop and livestock production.

An analysis of spatial diversity based on Perkal's index shows large variations in East Germany. The majority of Länder (60\%) shows the second type of development, that is stagnation. The highest $W_{\mathrm{i}}$ value was recorded in Saxony-Anhalt (0.57) due to the maximum values of its sub-indices $X_{2}, X_{3^{\prime}}, X_{4}, X_{6}$. At the same time, this province is characterised by the progressive nature of development (type I). The lowest $W_{i}$ value and a regressive nature of development was recorded in Brandenburg (-0.67), due to the minimum values of its sub-indices $X_{1}, X_{3}, X_{6}$. In the years 2002-2010 the share of the federal states in the particular types of development did not change. The fact that Thuringia changed its position from progress (type I) in 2002 to stagnation (type II) was compensated by Saxony-Anhalt shifting from the state of stagnation (type II) to that of progress (type I).

\section{Conclusions}

The study allowed determining the nature, pace and direction of change. The above analysis shows that in the period from 2002 to 2010 there were profound changes in Polish agriculture. They were mainly determined by the adjustment of the national agricultural policy to the acquis communautaire and resulted from implementing pre-accession assistance programmes (up to 2004) and then those of the Common Agricultural Policy. On the one hand, the above-mentioned activities intensified specialisation and modernisation processes in Poland's agriculture, the best example of which is the increase in the average size of an agricultural holding and growth in farming productivity. On the other hand, in many areas production extensified, reducing the pressure on the environment.

On the basis of Perkal's synthetic index, the voivodeships were delimited as those in a progressive and a regressive stage of development. Large disparities in the levels of development of individual regions were recorded. A spatial analysis of the selected sub-indices showed an increase in the maximum values and a decrease in the minimum ones. The minimum values 
were mainly recorded in the southern and eastern voivodeships, and the maximum values, in the western and northern ones. At the same time, there was an increase in the sub-indices, which indicates an increase in the level of crop and livestock production in the individual voivodeships. The values of the indicators characterising crop production account for around $60 \%$ of those recorded in the East German Länder. The size of livestock production is more diverse and ranges from $17 \%$ (sheep density) to $112 \%$ (pig density).

Over the analysed period, the ranking changed for Podlasie and Lubuska Land, which moved up to the state of stagnation (type II), as well as for Małopolska and Silesia, which moved down to the state of regression (type III). West Pomerania moved up to type I, mainly due to increased crop production in its area. Between 2002 and 2010 the range of variation and the degree of spatial dispersion of sub-indices changed, indicating a deepening of polarisation processes in Poland's agriculture. This situation runs counter to the European Union's basic assumptions of sustainable development, which aim at reducing the scale of inter-regional disparities. The results of this study indicate the need to take action to support the development of regional agriculture.

\section{References}

Agrarstruktur-Landwirtschaftszählung (Agricultural Census), 2010. Bundesministerium für Ernährung und Landwirtschaft, Berlin.

Ahrends K., Hoell G., 1989. Die Agrarverhältnisse im Sozialismus. Berlin: 23-25.

Brem M., 2001. Landwirtschaftliche Unternehmen im Transformationsprozess (Agricultural farms in the transformation process). Shaker Verlag, Aachen.

Brückner T., 1992. LPG - was nun? Agrarkonzentration im Osten Deutschlands. Die Neugestaltung des ländlichen Raumes. Internationalismus-Verlag, Hannover.

Grykień S., 2004. Przekształcenia w rolnictwie Europy Środkowo-Wschodniej ze szczególnym uwzględnieniem nowych krajów zwiąkowych Niemiec, Polski i Ukrainy (Transformation in the agriculture of East-Central Europe, with particular reference to the new Länder in Germany, Poland and Ukraine). Wyd. Uniwersytetu Wrocławskiego, Wrocław.

Hoffman H., 1993. Die Landwirtschaft in der DDR und der Übergang zur europaorientierten markwirtschaftlichen Strukturen in Mecklenburg-Vorpommern (Agriculture in the German Democratic Republic and the transition to market-based Europe-oriented structures in Mecklenburg-Vorpommern). Heft 4, Rostock.
Instrumenty oddziaływania Państwa na kształtowanie struktury obszarowej gospodarstw rolnych w Polsce (Instruments of the State's impact on the size structure of farms in Poland). 2009. Ekspertyza dla Ministerstwa Rolnictwa i Rozwoju Wsi, Instytut Ekonomiki Rolnictwa i Gospodarki Żywnościowej, Warszawa.

Janzen J., Sadler W., 1993. Der Wandel im ländlichen Raum des östlichen Brandenburg (The change in rural areas of eastern Brandenburg). In: Eckart K., Marcinek J., Viehrig $\mathrm{H}$. (eds), Räumliche Bedingungen und Wirkungen des sozial-ökonomischen Umbruchs in Berlin-Brandenburg. Schriftenreihe der Gesellschaft für Deutschlandforschung, Bd. 36: 63-70.

Jasiulewicz M., 1998. Przeksztatcenia strukturalne i przestrzenne obszarów wiejskich Pomorza Środkowego w okresie transformacji systemowej (Structural and spatial changes in rural areas of Central Pomerania in the period of the systemic transformation). Wyd. Uczelniane Politechniki Koszalińskiej, Koszalin: 112-136.

Jezierska-Thöle A., 2010. Wpływ Wspólnej Polityki Rolnej na funkcjonowanie sektora rolnego w Niemczech Wschodnich na przykładzie Brandenburgii (Impact of the Common Agricultural Policy on the functioning of the agricultural sector in East Germany: the case of Brandenburg). In: Rudnicki R. (ed.), Rola środków Unii Europejskiej w rozwoju obszarów wiejskich. Studia Obszarów Wiejskich, 23, IGiPZ PAN, Warszawa: 89-105.

Jezierska-Thöle A., 2012. Zróżnicowanie przestrzenne gospodarstw rolnych Polski i Niemiec według liczby i grup wielkościowych (Spatial diversity of farms in Poland and Germany by number and size). In: Kurowska K., Gwiaździńska-Goraj M. (eds), Planowanie rozwoju przestrzeni wiejskiej. Studia Obszarów Wiejskich 29, IGiPZ PAN, Warszawa: 45-65.

Namyślak B., 2007. Zastosowanie metody wskaźników przyrodniczych Perkala do badania poziomu konkurencyjności regionów (Application of the method of Perkal's natural indicators to examine the competitiveness level of regions). Wiadomości statystyczne 9: 58-70.

Obszary wiejskie w Polsce. Studia i analizy porównawcze (Rural areas in Poland. Studies and comparative analysis). 2011. Główny Urząd Statystyczny, Urząd Statystyczny w Olsztynie, Warszawa, Olsztyn.

Raport z wyników, Powszechny Spis Rolny (Agricultural Census: Report of results). 2010. GUS, Warszawa: 26-31.

Rudnicki R., 2010a. Zróżnicowanie przestrzenne wykorzystania funduszy Unii Europejskiej przez gospodarstwa rolne w Polsce w latach 2004-2006 (Spatial differences in the use of European Union funds by agricultural hioldings in Poland over the years 2004-2006). Studia i Prace z Geografii i Geologii 17, Bogucki Wydawnictwo Naukowe, Poznań.

Rudnicki R., 2010b. Acquisition of European Union funds by agricultural holdings and differences in the spatial structure of farming in Poland. In: Churski P., Ratajczak W. (eds), Regional development and regional policy in Poland: First experiences and new challenges of the European Union membership. Polish Academy of Sciences Committee for Spatial Economy and Regional Planning, Studia Regionalia vol. 27, part II, Warsaw: 79-93.

Situationsbericht, 2012. Die wirtschaftliche Lage der landwirtschaftlichen Betriebe. Buchführungsergebnisse der Testbetriebe (The economic situation of farms. Accounting results of test enterprises). Bundesministerium für Ernährung, Landwirtschaft und Verbraucherschutz, Berlin. 
Statistisches Jahrbuch des Bundesrepublik Deutschland (Statistical yearbook of the Federal Republic of Germany), 2011. Staatliche Zentralverwaltung für Statistik, Berlin.

Strategia Rozwoju Rolnictwa na lata 2007-2013 (Agricultural Development Strategy). Ministerstwo Rolnictwa i Rozwoju Wsi, Warszawa.
Szymla Z., 2000. Determinanty rozwoju regionalnego (Determinants of regional development). Ossolineum, Wrocław.

Użytkowanie gruntów. Powszechny Spis Rolny (Land use. Agricultural Census). 2011. Główny Urząd Statystyczny, Warszawa. 